\title{
Reflections on Refuge in Hungary: A New Host Country
}

\author{
Earl Noelte
}

Since 1988 Hungary has increasingly become a refuge for people who seek asylum and refugee status. ${ }^{1}$ Immigration, which included a substantial number of ethnic Hungarians from Romania, as identified in Table 1, passed through three important phases. The last phase - the inflow of refugees from Croatia and Serbia - continues to receive a critical response from many levels of society and government in Hungary. The refugee regime's international community recognizes Hungary's vital importance as a new refugee-hosting country in Central Europe.

Hungary became a new host country for refugees for internal and external reasons. Hungary's model of an alternative between a socialist and a capitalist market economy began in $1968 .^{2}$ By the 1980 s, economic alternatives to a rigid, socialist market system found their societal and political counterparts in emerging intellectual and social movements. These groupings and associations - which addressed environmental, peace and minority issues - were to provide a focus of interest for Hungarian political parties by 1989 . Hungary's pluralism and democratization evolved over a period of two decades and gave the country an image of transitional change prior to the major turning-point of Eastern Europe's transformation at the end of 1989.

Hungary's image of transition with stability continues to hold great consequence for the nation. The population is 10.6 million people. In addition, important ethnic Hungarian populations reside outside of Hungary. Theseneighbouring populationsinclude two million people in Romania; 250,000 in Ukraine; 800,000 in Slovakia; and 300,000 in Croatia and Serbia. These

Earl Noelte is the Director of the Refugee Studies Program at Webster University in Geneva, Switzerland. populations' sociocultural transnational Hungarian identity directs their consciousness to the sovereign nationstate of Hungary, which means that respect, as well as lack of respect, for Hungarian individual, group and minority rights is aninterest and concern that the Hungarian government cannot disregard. Therefore, the nation-state of Hungary has a permanent pull factor on ethnic Hungarian populations that reside outside of Hungary. The effect of this pull factor was partly responsible for the first wave of ethnic Hungarians refugees who flooded into Hungary from Romania in 1988. Romania's

\section{Hungary's image of transition with stability continues to hold great consequence for the nation.}

repressive Ceausescu regime was the second factor that caused 11,745 ethnic Hungarians to seek asylum in Hungary this year. Severe hardship and lack of respect for ethnic Hungarians' rights in Transylvania drove them to flee Romania and seek refuge in Hungary.

Hungary gave these "fellow Hungarians" a warm reception and generous assistance. A network of nongovernmental organizations was established to coordinate the reception, assistance and assimilation of these refugees. As well, the government of Hungary organized its Department of Refugee Affairs in the Ministry of the Interior after the first wave of ethnic Hungarian refugees from Romania arrived and settled.

Two nongovernmental organizations, the Hungarian Red Cross and the Ecumenical Council of Churches in Hungary, were instrumentalin receiving these refugees. Governmental authorities in Budapest, Bekescsaba and
Debrecen subsequently recognized the need to receive and provide for the refugees. Refugee admission centres opened to accommodate their basic needs. Unlike the fate of so many other refugees at admission and reception centres, the ethnic Hungarians spent only two to three weeks at Hungarian refugeeadmission centres. Hungary had the socio-economic means to meet the housing, employment, health and educational needs of this first wave of refugees. Therefore, the decision to host, facilitate family reunification and assume costs of assimilation became an integral part of Hungarian social politics. At the same time, Hungary became the front yard of refuge in Central Europe.

The consequences of Hungary's shift to the front yard of Central and (by the end of 1989) "new Europe" were considerable. First, Hungary became a model for hosting refugees, mostly ethnic Hungarians from Romania. In 1989 and 1990, which mark the second phase of refugee inflows into Hungary, the totals were 10,821 and 14,953 respectively. During this phase the Hungarian government signed the 1951 Convention and the 1967 Protocol relating to the Status of Refugees, which became effective in Hungarian law on October 15, 1989. Although Hungary reserved the right to refugee status for individuals of European origin, ${ }^{3}$ it was the first former East European state to become a party to the United Nations High Commissioner for Refugees (UNHCR) and to gain a prominent position in the international refugee regime. Furthermore, Hungary's model was used by other East European states - Poland, Czechoslovakia and, in time, even Romania. Therefore, Hungary became the centre of a front line between Eastern and Western Europe.

The second consequence of Hungary's shift to the front yard and then to the front line of Eastern Europe put Hungary into the backyard of 
Western Europe. In fact, Hungary became a shield that held back forced migration from Eastern to Western Europe. These fundamental transformations began to make increasing demands on Hungary's capacity to host asylum seekers and refugees. At the same time, Hungary's expectations of assistance from the UNHCR and the international refugee regime were not met. Also, the initial socio-political consensus to host, assist and assimilate refugees began to wane. Towards the end of the second phase of refugee movement into Hungary in late 1990, socio-economic discrimination towards ethnic Hungarians began to spread towards other Europeans (for example, Albanians) and non-European asylum seekers and refugees in Hungary.

The change from warm reception to discrimination of asylum seekers and refugees was the third consequence of the country's shift to the front and the backyard of the "new Europe." Hungary's transition from a socialist to a liberal capitalist system depended on the pace with which markets and international (i.e., Western Europe and the United States) investments accumulated in Hungary. The government made a gradual transition, while politics became of vital interest to Hungarian pluralist groups and political parties. As a result of Hungary's democratization, all of the country's socio-political sectors participated in societal and political debates. At the same time, these debates increasingly coincided with negative socio-economic indicators. By 1991, inflation was at 36 percent; unemployment was at 8 percent; gross domestic production was 8

\section{Bearing the burden and acting as the front and the backyard of the "new Europe" seemed to be Hungary's particular position in the summer of 1991.}

percent. Housing shortages and strained social services in health and education also contributed to the change from an open reception to discrimination towards asylum seekers and refugees in Hungary.

The warm reception during the first two phases of refugee inflows into Hungary weakened and turned into discord by June 1991 . One popular solution to the problem was to help ethnic Hungarians in their communities of origin and thereby remove, at least in part, the causes for which these people

Table 1: Asylum Seekers and Refugees in Hungary*

$\begin{array}{lrrrrr} & 1988 & 1989 & 1990 & \text { June } 1991 & \text { Total } \\ \text { Asylum seekers } & 13,173 & 17,448 & 18,283 & 2,629 & \mathbf{5 1 , 5 3 3} \\ \text { From Romania } & 13,098 & 17,171 & 17,416 & 1,864 & \\ \text { ethnic Hungarians } & 11,745 & 10,821 & 14,953 & 1,864 & \\ \text { ethnic Romanians } & 1,097 & 5,545 & 2,358 & & \\ \quad \text { ethnic Germans } & 256 & 805 & 99 & & \\ \text { From Soviet Union } & & & 488 & 413 & \\ \text { ethnic Hungarians } & & & 213 & & \\ \text { others } & & & 275 & & \\ \text { From other countries } & & & 379 & & \\ \text { Recognized as refugees } & 95 & 2,561 & 149 & \\ \text { ethnic Hungarians } & & 2,409 & & \\ \text { others } & & 152 & \end{array}$

"Reproduced with the permission of Boldizsar Nagy, The Hungarian Refugee Law, Budapest, June 1991. might seek refuge in Hungary. Nongovernmental organizations and voluntary agencies began cross-border operations of assistance, for example, to Transylvania inside Romania. These initiatives seemed more appropriate as Hungary's capacity to host, assist and assimilate refugees waned. In fact, by June 1991 asylum seekers and refugees had to stay in Hungarian refugee admission centres for much longer periods than before. These people felt demoralized and marginalized from Hungarian society. Signs of alienation were even stronger for nonethnic Hungarian refugees, whose opportunities for third country resettlement in Western Europe, Canada or the United States had greatly diminished to nothing more than an illusion. ${ }^{4}$

Bearing the burden and acting as the front and the backyard of the "new Europe" seemed to be Hungary's particular position in the summer of 1991. The Department of Refugee Affairs in the Ministry of the Interior organized a centre to respond to forced migration into Hungary. Also, illegal immigration and human smuggling were taking place through Hungary's "green border" with Romania. At the same time, economic migrants sought socio-economic opportunities in Hungary or migrated through Hungary to Western Europe and North America. As the categories of population movement became more numerous, all parties in Hungary recognized the need to inform and educate the public and thereby reconstruct the earlier consensus with respect to reception, assistance and assimilation of refugees.

At the same time, all the parties in Hungary perceived a future wave of asylum seekers, refugees and economic migrants. This flood, which was expected to come from the former U.S.S.R., would subject Hungary to successive waves of population movement into and maybe even out of the country. The population influxacross the Ukrainian border was estimated from one to two million people. An operational network of governmental and nongovernmental organizations was in place in the northeast region of Hungary to handle the expected influx. 
The reality, however, was different. Yugoslavia's war of societal and state conflict caused the third wave of refugees into Hungary. By November 19916,000 asylum seekers arrived daily, and by March 1992 there were 50,000 registered refugees from Croatia and Serbia. Hungary's response during this third phase seems to support the image and model of its original consensus at the end of the 1980s. Certainly receiving and assisting these refugees influenced Hungarian attitudes. Also, the arrival of these refugees into southwest Hungary - a new regional reception area facilitated theirreception and settlement. Once again, the major actors were the Department of Refugee Affairs, the Hungarian Red Cross and the Ecumenical Council of Churches. Assistance from the international refugee regime and the European Community was slow to materialize. Once more, Hungary acted as a shield, which gave further legitimacy to its front and backyard position in the "new Europe."

\section{Conclusion}

Hungary's profound transformations since 1988 have occurred at all levels subnational, national, transnational, regional and international. In becoming a new host country, Hungary experienced three important phases of forced migration during the past four years. Hungarians' transnational identity undoubtedly contributed to their positive reception of ethnic Hungarian refugees. This shared ethnic identity, however, was not strong enough to prevent discrimination towards refugees in 1990 and 1991 . Socioeconomic constraints and political uncertainties removed the earlier, favourable consensus to host, assist and assimilate asylum seekers and refugees in Hungary.

Hungary's transformation into the front and backyard of the "new Europe" became a complex set of internal and external Hungarian relationships. The legitimacy that the new host country gained within the international refugee regime and thereby for the West was certainly a gain in status for Hungary. At the same time, however, this country did not receive - at least not soon enough the expected financial or political assistance, i.e., third country resettlement for non-Hungarian refugees, which was necessary if Hungary was to be a model and effective key member of the new front line between Eastern and Western Europe. Increasingly, Hungary acted as a shield in response to the societal and political conflicts that displaced ethnic and nonethnic Hungarian populations. A current example is, of course, the refugee inflow from Croatia and Serbia.

Hungary's immediate future is uncertain. Its transformation to a liberal capitalist system is not yet complete.

\section{The reality, however, was different. Yugoslavia's war of societal and state conflict caused the third wave of refugees into Hungary.}

Political and economic demands have been made on Hungarian society demands that severely test the societal consensus necessary for the democratization process to develop in this country. Respect for individual, group and minority civil rights are an integral component of this democratization process. Developing a civil society in Hungary is a vital interest of the state and government. This civil society also forms the new core of the nation and the people of Hungary. Therefore, the strength and status of the Hungarian community - at both the state and interstate levels - are legitimate concerns and interests for the "new Europe" and the international community.

In fact, Hungary's identity must be more than its front and backyard position with regard to economic and forced migration in the "new Europe." Comprehensive and extensive interdependence - the right of solidarity is necessary for Hungary's security among European states and their transforming regional organizations. This greater interdependence would have to allow Hungary to drop its shield and thereby gain a multilateral security for its internal and external policies. Without this fundamental and necessary transformation, Hungary's future could become one of civil strife and societal conflict. These two classical causes of refugee flows would then revert Hungary from a new host country to a refugee-sending country. This should not happen.

\section{Notes}

1. Geza Tessenyi, "The Development of Immigration and Refugee Policy in a New Host Country: The Case of Hungary," The New Refugee Hosting Countries-Space for Innovation, SIM Special No. 11 (December 1991):109-128.

2. J. Ann Zammit, Dharam Ghai, Neelan Tiruchelvam and Bryan Turner, Hungary in Transition: From Socialism to Capitalism? (Geneva: United Nations Research Institute for Social Development and International Centre for Ethnic Studies, 1990). Also see "Central and Eastern Europe in Transition." Proceedings of a EuropeanJapanese Conference on Reform and Change in Eastern Europe in the 1990s, March 5-7, 1991. Arbeitspapiere zur Internationalen Politik, 64, Forschungsinstitut der Deutschen Gesellschaft fur Auswartige Politik e. V. and National Institute for Research Advancement (NIRA), Tokyo, August 1991.

3. Boldizsar Nagy, "Before or After the Wave? The Adequacy of the New Hungarian Refugee Law," Special Issue: The 1991 Geneva Colloquium, The 1951 Convention relating to the Status of Refugees: Principles, Problems and Potential. International Journal of Refugee Law 3, no. 3 (July 1991):529-39.

4. Material in this paragraph, as well as in those that follow, are taken from a study trip to Hungary in May 1991 and the VII Annual San Remo Seminar on "Societal Identity in Hungary and the New Central Europe," organized by the Refugee Studies Program, Webster University in Geneva, Switzerland, in cooperation with the International Institute of Humanitarian Law, San Remo, Italy, November 1991. 